\section{Natural resources and military expenditure: The case of Algeria}

\section{Sam Perlo-Freeman and Jennifer Brauner}

$\mathrm{G}^{\mathrm{s}}$

obal military expenditure has risen rapidly over the decade of the 2000s, reaching USD1,631 billion in 2010, an increase of 53 percent in real terms compared to $2000 .{ }^{1}$ Led by the United States, and followed by most countries and regions worldwide, one of the factors driving this trend lies in the ongoing efforts of the major global and regional powers to further develop their military power and influence. But another driver may lie in the large number of economically developing states whose natural resource revenue-derived from fossil fuel sales in particular-may provide the necessary income to help finance increases in military expenditure.

In one region, the Middle East, the link between oil and military expenditure has for a long time appeared so obvious as to be unremarkable. The region has by far the highest average ratio of military expenditure to gross domestic product. This is partly due to the high level of regional tension (in turn, partly due to conflict over fossil fuel resources), but also due to the sheer size of the oil and gas revenue that permits deals such as the Al-Yamamah series of arms contracts between the United Kingdom and Saudi Arabia. ${ }^{2}$

During the 2000s, a combination of high oil prices and new oil exploitation has generated high levels of revenue for many states of the developing world. In many cases, this has led to commensurate but extraordinarily high increases in military expenditure as well (see Table 1 for some examples). Other countries, such as Brazil, have seen less marked but still significant increases in military expenditure, but the link with oil is still apparent. Indeed, in Brazil's case, one justification that has been advanced for its purchase of submarines from France has been the need to protect newly-discovered offshore oil fields. ${ }^{3}$ Also in South America, Chile's relatively high level of military expenditure has been supported by the guaranteed 10 percent share of copper export revenue that constitutionally goes toward arms purchases, a revenue stream that has increased sharply in recent years with the increase in copper prices.

The next section discusses some of these trends and looks at the reasons why natural resource revenue might have an effect on military expenditure over and above the general level of a country's economic resources as measured by GDP, the economic variable most often used in analyzing the determinants of military expenditure. Then follows a case study of Algeria, a country that has seen considerable variation both in military expenditure as well as in oil revenue. This is done in two sections, the first of which presents background information on
Algeria's military, political, and economic development; and the second presents preliminary econometric results. The final section summarizes and concludes.

Natural resources, conflict, governance, and military expenditure $^{4}$

In recent years, the actual and potential role of natural resources in conflict and development has been extensively analyzed from the perspective of the so-called resource curse-the cycle of bad governance, political grievance, and armed conflict that can occur in states highly dependent on natural resource revenue. ${ }^{5}$ Natural resources can fuel conflict through numerous channels. Importantly, they can act as a ready source of actual funds for rebel movements. Even the potential for resource looting can motivate rebellion in the first place. ${ }^{6}$ Rather than seeking peace, profits to be made from resource exploitation can prolong conflict and can change what may have begun as a genuine national or social movement ("grievance" based) into a quasi-criminal organization whose primary objective is profit ("greed" based). Governments, too, can come to see maintaining their hold on resource exploitation as their primary raison d'être and use resourcebased revenue to fund ongoing war. The military itself may become involved in mineral exploitation, as in the DR Congo, and generate a pattern of associated human rights abuses that stimulate and exacerbate
Global military expenditure has risen rapidly over the decade of the 2000 s, reaching USD1.6 trillion in 2010, an increase of 53 percent in inflationadjusted terms as compared to the year 2000. One driver of this increase may lie in the large number of developing countries whose natural resource export earnings may have provided the income to finance military expenditure. This article explores this possible link with a case study of Algeria.

Table 1: Oil- and gas-producing states with large military expenditure increases

Country Mil. exp. increase, 2000-2009

$\begin{array}{lr}\text { Algeria } & 105 \% \\ \text { Azerbaijan } & 471 \% \\ \text { Chad } & 663 \% \\ \text { Ecuador } & 241 \% \\ \text { Kazakhstan } & 360 \% \\ \text { Nigeria } & 101 \% \\ \text { Timor-Leste [a] } & 255 \% \\ \text { Viet Nam [b] } & 55 \%\end{array}$

Source: SIPRI military expenditure database.

Note: All increases are in real terms. [a] Increase 2003-2009

[b] Increase 2005-2009 
violent conflict. Oil exploitation can cause adverse environmental effects, generating grievances as in the Niger Delta, where the failure of oil wealth to generate local economic benefits added another motive for rebellion. ${ }^{7}$

Natural resources can also carry negative consequences for governance. When handled in an opaque manner, bypassing normal budgetary procedures, people assigned to process natural resource revenue are susceptible to corruption. For example, bribes may be paid in return for exploitation concessions, a potential source of enormous personal enrichment for decisionmakers. Such concerns lie behind the Extractive Industries Transparency Initiative, which seeks to encourage companies to disclose what they pay to governments for resource concessions and for governments to openly account for resource revenue received. The voluntary nature of this initiative, however, perhaps limits its impact.

The potential implications of these and other issues for military expenditure are not hard to see but have rarely been the subject of detailed analysis. ${ }^{8}$ First, and quite aside from the governance and conflict issues, natural resources provide a direct source of revenue that does not require taxing of the general population. For developing countries especially, most of whom may have limited tax bases and tax collection abilities, such revenue plays a disproportionately large role in overall government revenue. This may affect public spending in general, and in particular may make it easier for governments to engage in what might otherwise be unpopular major arms purchases-were they to be funded through taxation.

Second, the potential of natural resources to fuel conflict is itself likely to be a spur to military expenditure, both through the general cost of waging conflict and because resources are often a specific target of rebel groups, for example the widespread attacks on oil infrastructure in the Niger Delta that have led to major reductions in Nigeria's oil output. ${ }^{9}$ Even where conflict does not actually occur, the desire to protect, for instance, oilfields from actual or potential internal or external threats may provide a motive for military expenditure. ${ }^{10}$

Third, low levels of transparency and correspondingly high levels of corruption potential may facilitate higher military expenditure, especially when such revenue can be a source of off-budget military expenditure. ${ }^{11}$ In Chile, for instance, this goes through the copper law in a much more transparent manner than is usually the case, but still allows the military a guaranteed funding stream regardless of security needs. In particular, natural resource revenue is used to directly, and often nontransparently, fund major arms purchases. Such revenue provides a direct source of foreign currency, even as arms procurement contracts offer lucrative potential for bribes. Transparency International, a nongovernmental monitoring and advocacy group, considers the arms market to be one of the most corrupt legal industries in the world. ${ }^{12}$ While off-budget purchases may not always find their way into published military expenditure figures, the acquired weapons will generate additional operations and maintenance costs.

A more subtle effect of resource revenue on military expenditure may be through its impact on the nature of the state. A state that is highly dependent on resource revenue may lead to a regime whose hold on power, and thus on the flow of resource revenue, depends more on keeping control of the revenue-generating infrastructure than on promoting the general economic development of the populace. ${ }^{13}$ Thus, the military may acquire greater significance as the guarantor of regime survival. In contrast, governments dependent on general taxation have more need to maintain the consent of the governed.

These multiple potential channels of influence result in a strong a priori case for the proposition that natural resource revenue, and in particular high dependence on such revenue, may promote higher military expenditure. The examples of the Middle East and of the states presented in Table 1-of rapid military expenditure growth in recent years in certain oil-producing countries-provide at least anecdotal support for this hypothesis. But as yet, there has been little by way of systematic empirical testing. Most studies of the determinants of military expenditure limit themselves to GDP as a measure of resource availability. In this article, we begin to rectify this shortcoming in the literature.

\section{Algeria: Background}

At current prices, Algeria is thought to sport Africa's highest military expenditure, USD5.2 billion in 2008, as compared to USD3.5 billion for second-placed South Africa. This increased dramatically from 1992 onward, reflecting the outbreak of Algeria's civil war, but then continued to rise even after the war waned in 2000 (see Figure 1). In fact, Algeria recently launched major efforts to modernize its military, entering into a USD7.5 billion arms deal with Russia in 2006, as well as smaller deals with China, the United States, and various European suppliers. ${ }^{14}$ These efforts may be motivated by at least three factors. First, albeit diminished since the 1990s, Algeria is responding to the continued threat posed by Islamic insurgents. But the types of equipment procured are not best-suited for counterinsurgency operations. ${ }^{15}$ Second, Algeria seeks to boost its international influence and regional leadership ahead of its neighbors, Morocco in particular. Third, Algeria's efforts may be interpreted as a government attempt to appease the military. Even as the country takes cautious steps toward democracy, engages in modest economic privatization, and sees a diminishing role of the armed forces, the military remains a significant player behind the scenes. ${ }^{16}$

Described as “the real power in Algeria," the military descended directly from the revolutionary army. Deriving its legitimacy from the central role it played in liberating the country from France in an ugly, decade-long struggle, it perceives itself as "the true guarantor of the principles and aspirations of the Algerian revolution and statehood," with a continuing, major part to be played in politics. The military is closely linked with Algeria's ruling party, the National Liberation Front (FNL). ${ }^{17}$ One observer explains that "the [FLN] movement was in a sense 


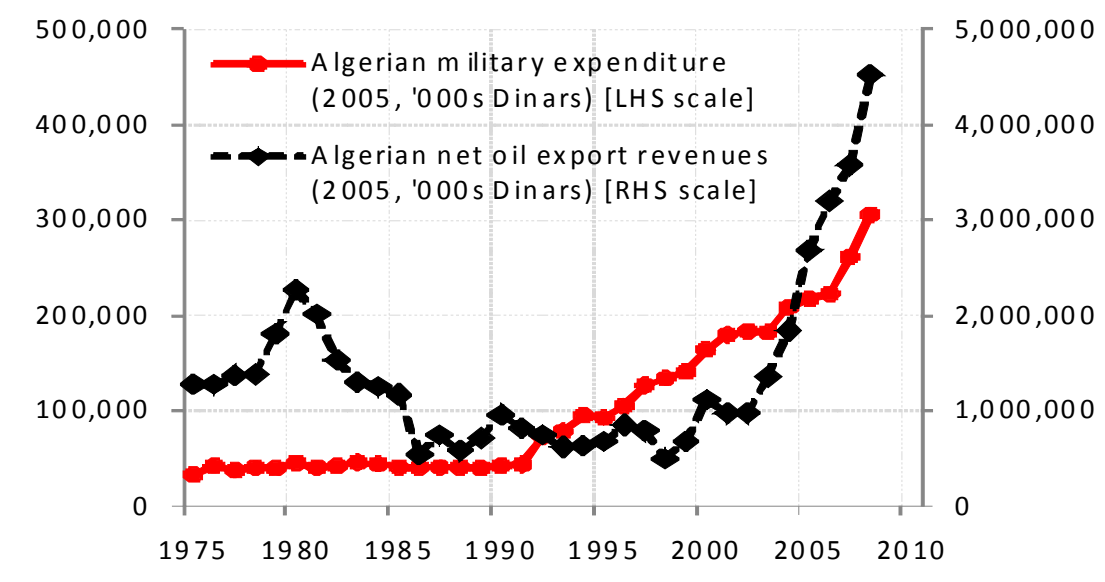

Figure 1: Algerian military expenditure and net oil export revenue, 1975-2008. Sources: See text.

reintegrated or absorbed into the army in the form of populist ideology ... the army thereby came to embody the historical heritage of the FLN." ${ }^{\prime 18}$ The military holds key positions in government. In particular, it has had a disproportionately large say in determining Algeria's leadership, with several of the country's presidents drawn directly from its own ranks. In 1992, the military stepped in when the Islamic Salvation Front's success in Algeria's first multiparty national elections threatened the position of the FLN. The military pressured then-President Bendjedid into resigning, cancelled the elections, and appointed a five-member High Council of State to act as a collective presidency. Violence ensued and a state of emergency was declared under which the military was granted certain direct powers, for example, when dealing with insurgency and terrorism. ${ }^{19}$ Since the civil war ended, the military has withdrawn from center stage, but it continues to exert its influence. For example, although Algeria's presidents are no longer recruited directly from the ranks of the military, a support base within the military High Command continues to be an informal requirement for the position. The current president, Abdelaziz Bouteflika, owes his position to the support of the military.

Algeria's military expenditure is funded in part by revenue from oil and gas exports. The country is the fourth largest crude oil producer in Africa, and the sixth largest natural gas producer in the world. Accounting for roughly 30 percent of GDP, 60 percent of budget revenue, and 95 percent of export earnings, hydrocarbon exports form the backbone of the Algerian economy and have been central to the government's strategy for the development of the country. ${ }^{20}$ The industry was completely nationalized in 1971 and has since been organized by a state-owned company, Sonatrach, which is particularly close to government. Top positions in the company are frequently filled by former energy ministers, and vice versa, and it is noteworthy that while many sectors of the once nationalized economy are gradually being privatized, the energy sector remains under firm government control. ${ }^{21}$ Tellingly, part of the 2006 arms deal with Russia included production-sharing agreements for Russian energy companies in Algerian oil and gas interests in return for price concessions for the arms procured. ${ }^{22}$ Analysts reason that the government's continued control over the hydrocarbon sector is motivated by the links between oil and gas rents and the ability to fund military expenditure.

In the following section, we explore the statistical link, if any, between Algeria's natural resource revenue and military expenditure. We analyze time series of data spanning 34 years, from 1975 to 2008.

Algeria: Military expenditure and oil revenue

\section{Method and data}

We explore the relationship between Algerian military expenditure and oil export revenue (Figure 1) using a general to specific approach. We begin by estimating a general equation and then remove variables based on their joint significance and on the Akaike Information and Schwartz Bayesian criteria (AIC and SBC). Our most general equation is:

$\left(\log \_ \text {milex }\right)_{t}=\beta_{0}+\left(\beta_{1}\right)\left(\log \_m i l e x_{t-1}\right)+\left(\beta_{2}\right)\left(\log \_\right.$milex $\left._{t-2}\right)+\left(\beta_{3}\right)\left(\log \_o i l_{t}\right)+$

$\left(\beta_{4}\right)\left(\log \_o i l_{t-1}\right)+\left(\beta_{5}\right)\left(\log \_o i l_{t-2}\right)+\left(\beta_{6}\right)\left(\log _{-} g d p_{t}\right)+\left(\beta_{7}\right)\left(\log _{-} g_{d p} p_{t-1}\right)+$

$\left(\beta_{8}\right)\left({\left.\log \_g d p_{t-2}\right)}\right)\left(\beta_{9}\right)\left(\log \_\right.$morocco $\left._{t}\right)+\left(\beta_{10}\right)\left(\log \_\right.$morocco $\left._{t-1}\right)+$

$\left(\beta_{11}\right)\left(\log \_\right.$morocco $\left.\mathrm{t}_{\mathrm{t}-2}\right)+\left(\beta_{12}\right)($ conflictdummy $)+\mathrm{e}_{\mathrm{t}}$,

where

- log_milex is the logarithm of Algerian military expenditure (in millions of constant [2005] dinars);

- log_oil is the logarithm of net oil export revenue (in millions of constant [2005] dinars);

- log_gdp is the logarithm of GDP (in millions of constant [2005] dinars);

- log_morocco is the logarithm of Moroccan military expenditure (in constant [2005] U.S. dollars);

- conflictdummy is a dummy variable controlling for wars and minor conflicts; and the subscripts

- $\mathrm{t}, \mathrm{t}-1$, and $\mathrm{t}-2$ refer to time and time lagged by one or two years, respectively.

We include GDP as a measure of the government's capacity to fund military 
expenditure through general taxation and expect GDP to have a positive effect on military expenditure. A better measure to use may be total tax revenue but this is potentially endogenous as raising tax revenue may be influenced by how much the government wants to spend. We also consider Moroccan military expenditure. Considerable tension exists between the two because Algeria rejects Morocco's administration of Western Sahara and supports the Polisario Front's aspiration for independence there. Tension continue, even after a cease-fire was agreed in 1991. In turn, Morocco is wary of Algeria's dominant military capabilities, and analysts suggest that Algeria's recent arms procurement spree could intensify this rivalry. ${ }^{23}$

Finally, we include a dummy variable for the period during which Algeria has been in conflict, taking a value of 1 for the period from 1992 onward (since when there have been over 100 battle-related deaths each year, according to the Uppsala Conflict Database), and zero before that. ${ }^{24}$

Our annual data cover the period 1975 to 2008 which, while shorter than ideal, is at least clearly greater than 30 observations, often taken as a minimum requirement to carry out statistical work. Our data is compiled from various sources. With the exception of Moroccan military expenditure which is in constant (2005) U.S. dollars, all data is transformed into millions of constant (2005) dinars where relevant. Data on military expenditure both for Algeria and Morocco are taken from SIPRI's military expenditure database <www.sipri.org>. Data on Algerian net oil export revenue is provided by the United States Energy Information Administration <www.eia.doe.gov $>$. Regrettably, we could not find reliable data on gas export revenue. But these appear much smaller than oil revenue, so the omission is not likely to much affect our results. According to OPEC, in 2010, for example, Algeria's oil export revenue was USD53.2 billion out of a total oil and gas export revenue of USD55.7 billion, making gas less than 5 percent of the total. ${ }^{25}$ Data on Algerian GDP is taken from the World Bank's World Development Indicators $<$ www.worldbank.org $>$.

\section{Estimation results}

Table 2 summarizes the results for our general to specific regressions. The fourth regression (Model 4) returns the highest adjusted R-squared, measuring the closeness of the fit between estimated and actual data, adjusted for the number of variables included in the model. It also gives the best values of two other model diagnostic statistics used, the AIC and SBC. We also report the adjusted R-squared of the same models but using the first difference of log_milex as the dependent variable in the regression equation (d.log_milex in Table 2). This gives a more accurate idea of the goodness of fit of our model. According to this statistic our model is able to explain about 70 percent of the variation in the change of the logarithm in military expenditure. Statistically, the logarithm of net oil export revenue is highly significant in explaining Algerian military expenditure: A 10

Table 2: Algeria: General to specific regressions

Dependent variable: $\log \_\operatorname{milex}(\mathrm{t})$

\begin{tabular}{|c|c|c|c|c|}
\hline & Model 1 & Model 2 & Model 3 & Model 4 \\
\hline log_milex(t-1) & $\begin{array}{l}0.298 * * \\
(0.1358)\end{array}$ & $\begin{array}{l}0.3112 * * \\
(0.1242)\end{array}$ & $\begin{array}{l}0.357 * * * \\
(0.1265)\end{array}$ & $\begin{array}{l}0.3208 * * * \\
(0.1171)\end{array}$ \\
\hline log_milex(t-2) & $\begin{array}{l}0.3487 * * \\
(0.1385)\end{array}$ & $\begin{array}{l}0.352 * * * \\
(0.1268)\end{array}$ & $\begin{array}{l}0.3779 * * * \\
(0.1133)\end{array}$ & $\begin{array}{l}0.3423 * * * \\
(0.1203)\end{array}$ \\
\hline log_oil(t) & $\begin{array}{l}0.0773 \\
(0.0635)\end{array}$ & $\begin{array}{l}0.07413 \\
(0.0503)\end{array}$ & $\begin{array}{l}0.0887 * * * \\
(0.027)\end{array}$ & $\begin{array}{l}0.1042^{* * *} \\
(0.027)\end{array}$ \\
\hline log_oil(t-1) & $\begin{array}{l}0.0439 \\
(0.0756)\end{array}$ & $\begin{array}{l}0.0478 \\
(0.0541)\end{array}$ & & \\
\hline log_oil(t-2) & $\begin{array}{l}0.0013 \\
(0.06)\end{array}$ & & & \\
\hline log_gdp(t) & $\begin{array}{l}-0.4388 \\
(0.7735)\end{array}$ & $\begin{array}{l}-0.4433 \\
(0.6725)\end{array}$ & & $\begin{array}{l}-0.4141 \\
(0.6357)\end{array}$ \\
\hline log_gdp(t-1) & $\begin{array}{l}0.9166 \\
(1.0562)\end{array}$ & $\begin{array}{l}0.668 \\
(0.5879)\end{array}$ & & $\begin{array}{l}0.6235 \\
(0.5551)\end{array}$ \\
\hline log_gdp(t-2) & $\begin{array}{l}-0.2158 \\
(0.6548)\end{array}$ & & & \\
\hline log_morocco(t) & $\begin{array}{l}-0.0706 \\
(0.1186)\end{array}$ & $\begin{array}{l}-0.0706 \\
(0.1007)\end{array}$ & & \\
\hline log_morocco(t-1) & $\begin{array}{l}-0.0103 \\
(0.1127)\end{array}$ & $\begin{array}{l}-0.02 \\
(0.0988)\end{array}$ & & \\
\hline log_morocco(t-2) & $\begin{array}{l}-0.0371 \\
(0.116)\end{array}$ & & & \\
\hline conflictdummy & $\begin{array}{l}0.4932 * * * \\
(0.0755)\end{array}$ & $\begin{array}{l}0.477 * * * \\
(0.0642)\end{array}$ & $\begin{array}{l}0.4536 * * * \\
(0.0627)\end{array}$ & $\begin{array}{l}0.4603 * * * \\
(0.0577)\end{array}$ \\
\hline constant & $\begin{array}{l}-0.9234 \\
(1.7613)\end{array}$ & $\begin{array}{l}-0.7343 \\
(1.5958)\end{array}$ & $\begin{array}{l}1.5907 * * * \\
(0.3959)\end{array}$ & $\begin{array}{l}-0.9191 \\
(1.5059)\end{array}$ \\
\hline Observations & 32 & 32 & 32 & 32 \\
\hline R-squared & 0.9941 & 0.9940 & 0.9918 & 0.9937 \\
\hline Adj. R-squared & 0.9903 & 0.9915 & 0.9905 & 0.9922 \\
\hline $\begin{array}{l}\text { Adj. R-squared } \\
\text { with d.log_milex }\end{array}$ & 0.6329 & 0.6788 & 0.6413 & 0.7035 \\
\hline AIC & -69.3 & -74.8 & -74.8 & -79.3 \\
\hline SBC & -50.2 & -60.2 & -67.4 & -69.0 \\
\hline
\end{tabular}


percent increase in oil export revenue is associated with a 1.04 percent increase in military expenditure in the short-term (Model 4) and with a 2.8 percent increase in the long-term. ${ }^{26}$

In contrast, GDP is statistically insignificant in explaining Algerian military expenditure. This provides support for the proposition that there is something different about natural resource revenue that allows it to affect military expenditure directly. As discussed, unlike taxes levied on the population, natural resource revenue does not force the government to be accountable to its citizens. The conflict dummy results in a statistically highly significant positive coefficient on Algerian military expenditure. Based on the size of the coefficient, the armed conflict that began in 1991 is estimated to have led to a 58 percent short-term and 292 percent long-term increase in military expenditure. ${ }^{27}$ Finally, Moroccan military expenditure is statistically insignificant in explaining Algerian military expenditure. This is perhaps unsurprising, as Algeria has a far higher level of military expenditure than does Morocco. Morocco may feel threatened by Algeria's military capabilities, but the opposite is less likely to be the case. Moreover, observers believe that the threat of a reignited conflict between Morocco and Algerian-backed Polisario forces is remote. $^{28}$

Our results do not suffer from serial correlation or heteroskedasticity. ${ }^{29}$ A further potential problem is endogeneity between military expenditure and GDP (that the two may influence each other, making it impossible to tell the direction of causation and distorting the results), but GDP being statistically insignificant in explaining military expenditure suggests that this is not a problem here. We noted earlier that there was a sharp upward trend in military expenditure in 1992. This reflected the outbreak of the civil war, but continued even after the war waned in early 2000. It is possible that the relation between the dependent variable and the regressors changed after 1992 . We therefore tested for a structural break, that is, whether the coefficients of the independent variables changed as from 1992. This test found no evidence of a structural break. ${ }^{30}$

Overall, the results provide initial evidence that oil revenue has influenced Algerian military expenditure. The results should be treated tentatively, in particular as they varied somewhat according to specification. For example, the inclusion of a time-trend dummy after 1992 renders all other variables, including lagged military expenditure, apart from the conflict dummy, statistically insignificant (although this would provide more of a description of Algerian military expenditure than an explanation). Despite this caveat, the qualitative story remains quite telling: Algerian military expenditure increased rapidly as a result of the civil war; then, despite its waning, continued to rise at essentially the same rate, just at the time when oil revenue was taking off. This revenue made possible new spending to be directed, not anymore to fighting the armed conflict, but toward a major equipment modernization program that is propelling Algeria to a position of being a dominant regional power. It is hard to see how such a program would have been financed without the oil revenue.

\section{Summary and conclusion}

Military expenditure worldwide has risen dramatically over the 2000s. Some of the most dramatic rises in military expenditure in recent years have been seen in countries with high levels of natural resource revenue, boosted both by increasing prices and by new development of oil and gas production in a number of countries outside the traditional major producing region of the Middle East. There are many reasons to suppose that natural resource revenue may have a particular role in fueling military expenditure, over and above the general level of GDP. They provide a direct source of government revenue not requiring taxation, and in particular a source of foreign currency for arms purchases. They can be a factor in provoking or prolonging conflict and can also create a demand for military power to protect extraction infrastructure. They can lead to nontransparent and corrup practices, which may favor off-budget military expenditure and large arms deals with lucrative bribe potential.

Algeria provides one case where this resource revenue-military expenditure hypothesis may be tested empirically. While the principal determinants of Algeria's military expenditure are political-the conflict with Islamist groups since 1992 (leading to very rapid military expenditure growth) and the powerful role of the military in Algerian politics - another potentially significant factor lies with the country's oil and natural gas revenue, which also has grown rapidly in recent years.

We estimated the determinants of military expenditure, using lagged military expenditure, GDP, oil revenue, Moroccan military expenditure, and a conflict dummy as independent variables. The results show that, apart from conflict, oil revenue was the only statistically significant variable, exerting a strongly positive effect on military expenditure. The fact that it was oil revenue, rather than GDP which was significant, suggests that this direct source of government revenue provides a much easier and politically attractive means of funding the military than does general taxation. While tentative, the results provide support for the main hypothesis, which we consider to be worthy of more systematic exploration through other case studies and through panel and cross-section studies.

\section{Notes}

Sam Perlo-Freeman is Head of the Military Expenditure Project at the Stockholm International Peace Research Institute (SIPRI). The corresponding author, he may be reached at < perlo-freeman@sipri.org>. Jennifer Brauner is a PhD student in economics at Birkbeck College, London.

1. Perlo-Freeman, et al. (2011). 
(C) www.epsjournal.org.uk - Vol. 7, No. 1 (2012)

2. See, e.g., Leigh and Evans (2007).

3. See, e.g., Perlo-Freeman, Perdomo, Sköns, and Stålenheim (2009).

4. The authors acknowledge the contribution of Prof. J. Paul Dunne in developing ideas for this section.

5. For discussion of different aspects of the issues, see, e.g., Kaldor, et al. (2007). Also see Bannon and Collier (2003), Collier and Hoeffler (2004), Hodler (2006), Le Billon (2005), and Ross (2001; 2004).

\section{Collier and Hoeffler (2004).}

7. See, e.g., Oyefus (2007) for a discussion of the role of oil in Nigerian conflicts.

8. Only occasionally is a dummy variable for oil-producing states included in regression analyses on the determinants of military expenditure. See, e.g., Deger (1986); Deger and Smith (1983).

9. See, e.g., “Attacks Cripple Shell’s Niger Delta Operations.” The Wall Street Journal. 19 July 2009.

10. For example, Brazil justified their recent purchase of submarines partly by the need to protect newly-discovered oilfields (see endnote 3.) Likewise, many of Nigeria's recent arms purchases have been related to protecting oil production in the Niger Delta from insurgents (see Perlo-Freeman, Ismail, and Solmirano, 2010).

11. See, e.g., Hendrickson and Ball (2002).

12. Courtney (2002).

13. See, e.g., Karl (1997).

14. Gelfand (2009, p. 23).

15. Gelfand (2009, p. 24).

16. Sorenson (2007, p. 105).

17. First quote: Cook (2007, p. 27). Second quote: Stone (1997, p. 129). From 1962 to 1989, Algeria was a single-party state, ruled by the FLN. Following the 1988 riots, a new constitution was adopted that allowed for the formation of other political parties. Nevertheless, the FLN has remained firmly in power, even through the “Arab spring” turmoil of 2011.

18. Addi (1998).

19. Stone (1997, p. 134).

20. Figures from Central Intelligence Agency (2010).

21. Entelis (1999, pp. 4; 11).

22. Vatanka and Weitz (2007, p. 39).

23. Vatanka and Weitz (2007, p. 39).

24. See www.pcr.uu.se/research/UCDP/index.htm. We initially used a more graduated conflict variable, but the simpler one/zero dummy proved more effective at explaining variations in Algerian military expenditure.

25. See http://www.eia.gov/cabs/OPEC_Revenues/Factsheet.html and “Algeria oil and gas revenues up 25 percent in 2010, minister,” AFP. 3 Jan 2011, http://www.energy-daily.com/reports/Algeria_oil_and_gas_revenues_up_25_per cent_in_2010_minister_999.html.

26. Equivalently, 0.104 and 0.28 are the short- and long-term elasticities of military expenditure (milex) with respect to oil revenue. The long-term figure is higher because of the influence of the previous two years' milex on the current year's milex. Thus, the initial increase due to oil revenue feeds through into further increases in later years. The long-term coefficient is calculated as the short-term coefficient divided by (one minus the sum of the coefficients of lagged milex), i.e., $1.04 /(1-0.3028-0.3423)=0.28$.

27. This is based on the conflict dummy coefficient in Table 2, and computed as $\exp (0.46)=1.58$, or a 58 percent increase for the short-term effect. See endnote 26 for the long-term effect computation.

28. For example, Vatanka and Weitz (2007, p. 39).

29. Serial correlation: Durbin's d-statistic $(7,32)=2.22$; Breusch-Godfrey test: $\chi 2(1)=1.01, p=0.3149$. Heteroskedasticity: Breusch-Pagan test: $\chi 2(1)=0.22$, $\mathrm{p}=0.636$. 
30. The test was performed by introducing slope dummies for the relevant variable, interacting the conflict dummy (=1 from 1992 onward) with the other variables in Model 4. This is equivalent to the standard Chow test, which could not be used directly as the conflict variable is already an intercept dummy. The result was $\mathrm{F}(5,20)=1.37, \mathrm{p}=0.2783$.

\section{References}

Addi, L. 1998. “Algeria’s Army, Algeria’s Agony.” Foreign Affairs. Vol. 77, No. 4, pp. 44-53.

Bannon, I. and P. Collier, eds. 2003. Natural Resources and Violent Conflict: Options and Actions. Washington, D.C.: World Bank.

Central Intelligence Agency. 2010. “Algeria," in The World Factbook. https://www.cia.gov/library/publications/the-world-factbook/geos/ag.html. [accessed 7 April 2010].

Collier, P. and A. Hoeffler. 2004. "Greed and Grievance in Civil Wars." Oxford Economic Papers. Vol. 56, pp. 663-695.

Cook, S.A. 2007. Ruling But Not Governing: The Military in Political Development in Egypt, Algeria, and Turkey. Baltimore, MD: The John Hopkins University Press.

Courtney, C. 2002. “Corruption in the Official Arms Trade.” Transparency International Policy Research Paper 001. London: Transparency International.

Deger, S. 1986. “Economic Development and Defense Expenditure.” Economic Development and Cultural Change. Vol. 35, No. 1, pp. 179-196.

Deger, S. and R. Smith. 1983. "Military Expenditure and Growth in Less-developed Countries.” Journal of Conflict Resolution. Vol. 27, No. 2, pp. 335-353.

[EIA] Energy Information Administration. 2010. "Country Analysis Briefs: Algeria.” Updated May 2009. http://www.eia.doe.gov/emeu/cabs/Algeria/ Background.html [accessed 7 April 2010].

Entelis, J.P. 1999. "Sonatrach: The Political Economy of an Algerian State Institution.” Middle East Journal. Vol. 53, No. 1, pp. 9-27.

Gelfand, L. 2009. “Spending to Thrive.” Jane’s Defence Weekly. Vol. 46, No. 4, pp. 22-27.

Hendrickson, D. and N. Ball. 2002. Off-Budget Military Expenditure and Revenue: Issues and Policy Perspectives for Donors. CSDG Policy Studies \#2. Conflict, Development, and Security Group. London: Department of War Studies, King’s College London.

Hodler, R. 2006. "The Curse of Natural Resources in Fractionalised Countries.” European Economic Review. Vol. 50, pp. 1367-1386.

Kaldor, M., T.L. Karl, and Y. Said, eds. 2007. Oil Wars. London: Pluto Press.

Karl, T. 1997. The Paradox of Plenty: Oil Booms and Petro-States. Berkeley, CA: University of California Press.
LeBillon, P. 2005. Geopolitics of Resource Wars: Natural Resources and Armed Conflicts. London: Routledge.

Leigh, D. and R. Evans. 2007. "The Al Yamamah Deal.” The Guardian. 7 June 2007. http://www.guardian.co.uk/world/2007/jun/07/bae15.

Oyefusi, A. 2007. "Oil-Dependence and Civil Conflict in Nigeria.” Working Paper WPS/2007-09. Centre for the Study of African Economies. Oxford University. http://www.csae.ox.ac.uk/workingpapers/wps-list.html.

Perlo-Freeman, S., C. Perdomo, E. Sköns, and P. Stålenheim. 2009. "Military Expenditure.” Chapter 5 in SIPRI Yearbook 2009. Oxford: Oxford University Press.

Perlo-Freeman, S., O. Ismail, and C. Solmirano. 2010. "Military Expenditure.” Chapter 5 in SIPRI Yearbook 2010. Oxford: Oxford University Press.

Perlo-Freeman, S., C. Cooper, O. Ismail,, E. Sköns, and C. Solmirano. 2011. “Military Expenditure.” Chapter 4 in SIPRI Yearbook 2011. Oxford: Oxford University Press.

Ross, M.L. 2001. Extractive Sectors and the Poor. New York: Oxfam America Report.

Ross, M.L. 2004. "What Do We Know About Natural Resources and Civil War?” Journal of Peace Research. Vol. 41, No. 3, pp. 337-356.

Sorenson, D.S. 2007. "Civil-Military Relations in North Africa.” Middle East Policy. Vol. 14, No. 4, pp. 99-114.

Stone, M. 1997. The Agony of Algeria. London: Hurst.

Vatanka, A. and R. Weitz. 2007. “Russian Roulette.” Jane's Intelligence Review. Vol. 19, No. 1, pp. 36-41. 